\title{
Orphan receptors in prostate cancer
}

\author{
Minas Sakellakis ${ }^{1}$
}

${ }^{1}$ Fourth Oncology Department and Comprehensive Clinical Trials Center, Metropolitan Hospital, 18547 Athens, Greece

* Correspondence: to: Minas Sakellakis, Fourth Oncology Department and Comprehensive Clinical Trials Center, Metropolitan Hospital, 18547 Athens, Greece. Phone: +306974644748; Fax: +302104814887; Email: doctorsakellakis@gmail.com

Running Title: Orphan receptors in prostate cancer.

\begin{abstract}
Background: The identification of new cellular receptors has been increasing rapidly. A receptor is called "orphan" if an endogenous ligand has not been identified yet. Methods: Here we review receptors that contribute to prostate cancer and are considered orphan or partially orphan. This means that the full spectrum of their endogenous ligands remains unknown. Results: The orphan receptors are divided into two major families. The first group includes $G$ protein-coupled receptors. Most are orphan olfactory receptors. OR51E1 inhibits cell proliferation and induces senescence in prostate cancer. OR51E2 inhibits prostate cancer growth, but promotes invasiveness and metastasis. GPR158, GPR110 and GPCR-X play significant roles in prostate cancer development and progression. However, GPR160 induces cell cycle arrest and apoptosis. The other major subset of orphan receptors are nuclear receptors. ROR $\alpha$ inhibits tumor growth, but ROR $\gamma$ stimulates androgen receptor signaling. PXR contributes to metabolic deactivation of androgens and inhibits cell proliferation. TLX has protumorigenic effects in prostate cancer, while its knockdown triggers cellular senescence and growth arrest. Estrogen-related receptor ERR $\gamma$ can inhibit tumor growth but ERR $\alpha$ is pro-tumorigenic. Dax1 and Shp are also inhibitory in prostate cancer. Conclusion: There is a "zoo" of relatively underappreciated orphan receptors that play key roles in prostate cancer.
\end{abstract}

Keywords: Orphan; receptors; nuclear; olfactory; prostate; cancer

\section{List of abbreviations}

GPCR: G protein-coupled receptor

cAMP: Cyclic adenosine monophosphate

FDA: Food and Drug Administration

LBD: Ligand-binding domain

DBD: DNA-binding domain

DNA: Deoxyribonucleic acid

FXR: Farnesoid $X$ receptor

LXR: Liver $\mathrm{X}$ receptor

ROR: Retinoic acid-related orphan receptor

PXR: Pregnane X receptor

TLX: Homologue of the Drosophila tailless

Dax1: Dosage sensitive sex reversal (DSS), adrenal hypoplasia congenita (AHC) critical region on the $\mathrm{X}$ chromosome, gene 1

Shp: Small heterodimer partner

AR: Androgen receptor

OR: Olfactory receptor 
MAPK: Mitogen-activated protein kinase

AKT: Protein kinase B

Rho: Rhodopsin

OR4A47: Olfactory receptor family 4 subfamily A member 47

GNAO1: G protein subunit alpha O1

GNA13: G protein subunit alpha 13

GNAI1: G protein subunit alpha I1

LNCaP: Lymph node carcinoma of the prostate (cell line)

PI3K: Phosphoinositide 3-kinase

NF-KB: Nuclear factor-kappa B

ERK1/2: Extracellular-signal-regulated kinase 1/2

TAS2R: Taste 2 receptor

MEK: Mitogen-activated protein kinase kinase

p38MAPK: p38 mitogen-activated protein kinase

PARP: Poly(ADP-ribose) polymerase 1

PIN: Prostatic intraepithelial neoplasia

TRAMP: Transgenic adenocarcinoma of the mouse prostate

ABCB1: ATP binding cassette subfamily B member 1

GPR158: G protein-coupled receptor 158

PTEN: Phosphatase and tensin homolog

PC3: Prostate cancer cell line

DU145: Prostate cancer cell line

RORE: ROR response elements

SRC: SRC proto-oncogene, non-receptor tyrosine kinase

ACTR: Acid tolerance regulatory protein

SULT2A1: Sulfotransferase family 2A member 1

CYP3A: Cytochrome p450 family 3 subfamily A

GFAP: Glial fibrillary acidic protein

Pax2: Paired box 2

H-Ras: Harvey rat sarcoma virus (oncogene)

CDKN1A: Cyclin dependent kinase inhibitor 1A

SIRT1: Sirtuin 1

HDAC1: Histone deacetylase

ERR: Estrogen related receptor

PGC1: Peroxisome proliferator-activated receptor gamma coactivator 1

ARE: Androgen response element

AKR1C3: Aldo-keto reductase family 1 member C3

AMPK: AMP-activated protein kinase

ER: Estrogen receptor

SRY: Sex-determining region $Y$

MiR-141: micro-RNA 141

\section{Introduction}

It has been recently discovered that steroid, retinoid and thyroid receptors constitute only a small fraction of a group of similar gene products. The identification of new classes of receptors with similar structures to existing ones, has been increasing at a rapid pace ${ }^{1}$. A receptor is called "orphan" if an endogenous ligand has not been identified yet ${ }^{2}$. If a ligand is later discovered, the receptor is referred to as "adopted orphan". This is the key to understanding their physiological role. Extensive research on these newly discovered receptors suggests that there are several cellular signaling pathways that remain to be discovered $^{2}$. 
The orphan receptors are divided into two major structurally distinct families 3,4 . The first group includes the $G$ protein-coupled receptors (GPCRs) ${ }^{3}$. They form a large group of evolutionarily-related proteins ${ }^{5,6}$. There are nearly 100 receptor-like genes that remain orphans in the GPCR family 6,7 . They are cell membrane receptors that interact with extracellular molecules to activate cellular responses. GPCRs pass through the outer membrane seven times and are coupled with Gproteins ${ }^{7}$. They are found only in eukaryotes and animals and they are activated by ligands such as neurotransmitters, odors, pheromones and hormones $7,8,9$. The signal transduction pathways that originate from GPCRs include either the phosphatidylinositol signal pathway or the cAMP signal pathway ${ }^{7,9}$. Their signaling pathways are involved in several diseases and currently about $34 \%$ of the FDA approved drugs target them ${ }^{10}$. There are five main phylogenetic families of GPCRs: glutamate, rhodopsin, adhesion, frizzled/taste2 and secretin. Approximately 49\% of GPCRs in humans are olfactory receptors. Despite the deorphanization efforts, most olfactory receptors still remain orphans ${ }^{7}$. Many taste receptors remain orphans as well ${ }^{11}$.

The other major subset of orphan receptors is the family of nuclear receptors ${ }^{1}$. They are cytosolic proteins. After ligand-binding activation, they change their spatial conformation and translocate to nuclear binding sites to act as transcription factors. They modulate gene expression in response to a wide range of physiological, developmental and environmental cues. Some nuclear receptors also mediate non-genomic effects that are too rapid to involve gene transcription changes. The nuclear receptors are usually composed of 4 different functional modules. These are the ligand-binding domain (LBD), the DNA-binding domain (DBD), the hinge region, and the modulator domain ${ }^{1}$. Examples of orphan nuclear receptors include the Farnesoid $X$ receptor (FXR), the Liver-X receptor (LXR), the Retinoic acid receptor-related orphan receptors (RORs), the Pregnane $X$ receptor (PXR), the TLX receptor, the Estrogen-related receptors, the Dax1 receptor, the Shp receptor, and others ${ }^{1,12,13}$. However, the endogenous ligands for FXR and LXR have been identified as bile acids and endogenous oxysterols respectively ${ }^{14,15}$. Hence, these receptors are considered adopted (i.e., de-orphanized).

Prostate cancer is the most frequently diagnosed cancer and the second leading cause of cancer-related death in American men ${ }^{16}$. The activation of androgen receptor (AR) signaling axis is of paramount importance, not only during the androgen sensitive stage, but also during the castration resistant stage ${ }^{17}$. However, it has been increasingly evident that other receptors also play important roles in prostate cancer development and progression, alone or in coordination with $\mathrm{AR}^{18}$. Examples not only include other steroid nuclear receptors such as the glucocorticoid and progesterone receptor, but also retinoic acid and retinoid $X$ receptors, the hepatocyte nuclear factor, the peroxisome proliferator-activated receptors, the liver $X$ receptors, and others ${ }^{18}$. Several G protein-coupled receptors and receptor tyrosine kinases are also of paramount importance ${ }^{19,20}$. Here we will review a few classes of receptors that contribute to prostate cancer tumorigenesis and progression, that are considered orphan or partially orphan. This means that the full spectrum of their endogenous ligands has not been discovered yet. 


\section{Olfactory receptors}

Olfaction is a form of chemosensation and is the most ancient human sense $^{21}$. Modern human olfactory receptors have evolved from ancient chemosensors that existed on the surface of primitive cells ${ }^{21,22}$. Odor molecules are detected by olfactory receptors that are predominantly located on the main olfactory epithelium in the nasal cavity. OR genes are the largest multigene family in the vertebrates, since there are thousands of different odors that need to be distinguished ${ }^{21,22}$. OR genes in the human genome account for approximately 400 functional genes and numerous pseudogenes ${ }^{22,23}$. ORs are G-protein-coupled receptors and they have seven transmembrane alpha-helical regions ${ }^{22}$. They belong to the superfamily of rhodopsin-like GPCRs and apart from odorants, other ligands include neurotransmitters, chemokines, peptides, lipids and nucleotides ${ }^{22,24}$. Only a small fraction of the activating odorants has been identified $^{25}$. Once ORs recognize odorant molecules, they activate a signal transduction pathway that leads to the perception of smell ${ }^{26,27}$. This process also regulates the apoptotic cycle of olfactory sensory neurons ${ }^{28}$. In addition, they activate pathways associated with proliferation, such as MAPK, AKT and $\mathrm{Rho}^{28}$. Some ORs also play a role in migration, as they mediate the projection of olfactory sensory neurons towards specific structures in the olfactory bulb ${ }^{28,29}$. However, ORs are also expressed in other non-nasal tissues and they likely have pleiotropic effects. For example, skin regeneration and hair growth can be regulated by $\mathrm{ORs}^{30,31}$.

Cancer cells in general express low levels of OR genes, but around 20 percent of tumors overexpress one or a few receptor genes. Around $70 \%$ of the cells that express at least one OR, overexpress only one specific receptor $^{28}$. Frequently, ORs overexpressed in cancer cells are normally silent in normal cells, suggesting that there is a different transcription repertoire in cancer $^{32}$. Commonly overexpressed ORs in tumor cells include OR4A47, OR4C46, OR6B2 and OR1D5 ${ }^{28}$. In addition, tumor cells that overexpress an OR also express the necessary functional effectors for signal transduction. Examples include the alpha subunits of a G-protein: GNAO1, GNA13, GNA15, GNAI1, GNAL and adenylate cyclase $3^{28}$. Overall, this suggests that the aberrant expression of ORs might contribute to the cancer phenotype. In cancer cells, ORs act as chemoreceptors $^{33}$. In comparison to healthy prostate tissue, prostate cancer shows a high tumor-specific overexpression (i.e., more than 10fold) of OR51E1 and OR51E2 in two-third of cases ${ }^{34}$. The full spectrum of their ligands is still unknown, but deorphanization efforts showed that they can be activated by lactate, butyric acid, propionic acid, and other aliphatic acids ${ }^{34}$. The activation of OR51E2 by the ligand beta-ionone leads to inhibition of prostate cancer cell proliferation, by blocking the androgen receptor nuclear translocation ${ }^{35}$. However, beta-ionone stimulation of OR51E2 in LNCaP cells promotes a PI3K-gammadependent increase in tumor invasiveness and metastatic potential ${ }^{36}$. The effects of beta-ionone are also likely mediated by MAPK activation and intracellular calcium ion increase ${ }^{37}$. In addition, changes in OR51E2 expression have been associated with activation of NF-kB and protein kinases ${ }^{34}$. OR51E2 is expressed in normal prostate epithelial tissue, which suggests that it might play a physiological role ${ }^{38}$. Moreover, experiments have shown that the activation of OR51E1 inhibits cell proliferation and 
induces senescence in prostate cancer $^{34}$. Upregulation of OR51E1 promotes cell death by increasing phosphorylation of ERK1/2 and upregulating $\mathrm{p} 53^{34}$. Olfactory receptors are also likely activated by steroid hormones, such as androstenone and androstadienone ${ }^{37}$. This suggests that androgen pheromones may initiate rapid non-genomic actions through OR activation ${ }^{37}$. In humans and other animals, pheromones are not only regulators of behaviour, but they affect neurogenesis and pose neuroendocrine effects as well (e.g., hypothalamus-pituitary-gonadal axis) ${ }^{39,40}$. Recent evidence suggests that 19-Hydroxyandrostenedione induces neuroendocrine transdifferentiation in prostate cancer cells via OR51E2 ${ }^{41}$.

\section{Taste receptors}

It has been shown that gustatory receptors also play a role in prostate cancer $^{42}$. Taste has evolved in animals to provide gratification from food $^{43}$. Similar to olfaction, gustation is behavior-modifying ${ }^{43,44}$. Bitter taste perception is critical for survival because it enables an organism to avoid the ingestion of potentially harmful substances ${ }^{44}$. Salty and sour compounds are linked to ion channels, while bitter, sweet and umami flavours are connected to G-protein-associated receptors ${ }^{45}$. Bitter taste receptors (TAS2Rs) have been identified in non-gustatory organs and have been linked to various diseases, including cancer ${ }^{46}$. In several tumor types, TAS2R activation exerts various anti-cancer effects, such as increased apoptosis and decreased cell proliferation and migration ${ }^{46,47,48}$. The expression levels of most TAS2Rs are diminished in prostate cancer cell lines compared to benign prostatic hyperplasia ${ }^{47}$. Recent studies suggest that noscapine causes a TAS2R14-dependent cell death induction and decreased viability in prostate cancer cells ${ }^{47}$. Bitter melon extract (BME) also selectively kills cancer cells (>90\%) and spares normal prostate epithelial cells ${ }^{49}$. Prostate cancer cells treated with bitter melon extract (BME) tend to accumulate in S-phase. BME strongly modulates cyclins, inhibits normal cell-cycle regulation, activates MEK-ERK or p38MAPK signaling pathways, enhances Bax expression and induces PARP cleavage ${ }^{49}$. It also induces apoptosis in prostate cancer cells and delays the progression of PIN in TRAMP mice ${ }^{49}$. In general, most TAS2Rs exert anticancer effects. A notable exception is TAS2R38, which is frequently overexpressed in cancer compared to normal tissue ${ }^{46}$. TAS2R38 can upregulate multidrug resistance protein $\mathrm{ABCB} 1$ and can induce chemoresistance in several tumor types ${ }^{46}$.

\section{Other orphan $\mathrm{G}$ protein-coupled receptors}

The G protein-coupled receptor 158 (GPR158) is an orphan receptor, which is a member of the glutamate family of GPCRs ${ }^{50}$. It plays a significant role in prostate cancer development and progression. It promotes tumor cell proliferation independently of $A R$, and this requires its localization inside the nucleus ${ }^{50}$. Moreover, GPR158 stimulates AR expression, while androgens stimulate GPR158 expression . This implies a potential role of the receptor in tumor sensitization to low androgen levels during androgen deprivation therapy. GPR158 is also associated with the development of neuroendocrine phenotype and promotes anchorage-independent tumor cell colony formation ${ }^{50}$. Increased expression is associated with lower disease-free survival. In a genetically 
defined conditional PTEN knockout mouse model, the expression of GPR158 was increased at the invading front of prostate cancer ${ }^{50}$. GPCR$X$ is another orphan $G$ protein-coupled receptor that is associated with cellular transformation and tumor growth in prostate cancer. Inactivation of this receptor in PC3 cells resulted in 80-100\% tumor regression rates in an athymic xenograft tumor model ${ }^{51}$. Moreover, seventeen percent of the mice became disease free. The effects of GPCR-X are mediated by downregulation of the cell adhesion pathway ${ }^{51}$. GPR110 is an orphan GPCR that is highly expressed in prostate cancer ${ }^{52}$. Lum et al. showed that staining with GPR110 antibody during immunohistochemistry, was able to differentiate between potential incipient malignancy and benign prostatic hyperplasia $^{52}$. On the contrary, GPR160 is an orphan GPCR that has been associated with cell cycle arrest and induction of apoptosis in prostate cancer cells ${ }^{53}$.

\section{Retinoic acid receptor-related orphan receptors}

Retinoic acid receptor-related orphan receptors (RORs) are nuclear receptors that include $\operatorname{ROR} \alpha, \operatorname{ROR} \beta$ and $\operatorname{ROR} \gamma^{54}$. They activate transcription through ligand-dependent interactions with coregulators ${ }^{54}$. They play important roles in brain and retinal development and drive naive T-cell lineage specification towards Th17 cells ${ }^{54,55}$. They are also involved in circadian rhythm regulation and metabolic homeostasis ${ }^{54}$. Several cholesterol derivatives and retinoids have been shown to regulate ROR activity ${ }^{54}$. Studies have found that ROR $\alpha$ and ROR $\beta$ act as tumor suppressors in several cancer types. On the contrary, ROR $\gamma$ plays diverse roles in distinct cancers ${ }^{54}$. Park et al. found decreased expression of ROR $\alpha$ in prostate cancer ${ }^{56}$. It has been shown that ROR $\alpha$ can inhibit cell proliferation in LNCaP cells, via the downregulation of Wnt target genes ${ }^{56}$. It can also induce growth arrest in DU145 cells, both in vitro and in vivo ${ }^{57}$. Moreover, $\operatorname{ROR} \alpha$ can control the metastatic behavior in subsets of androgen-independent tumors ${ }^{58}$. ROR $\gamma$ on the other hand, has been established as an important oncogenic driver in prostate cancer ${ }^{59}$. Although ROR $\gamma$ is overexpressed in about $50 \%$ of prostate adenocarcinoma, it is particularly amplified in metastatic castration-resistant disease. $\operatorname{ROR} \gamma$ protein is not detected in normal prostate epithelial cells ${ }^{59}$. It binds to an exonic RORE and directly stimulates androgen receptor gene transcription. The AR locus contains several putative ROREs. Furthermore, ROR $\gamma$ recruits the co-factors SRC1 and SRC-3/ACTR, that occupy the AR-RORE site ${ }^{59}$.

\section{Pregnane $X$ receptor}

The Pregnane $X$ receptor (PXR) is a nuclear receptor that regulates genes encoding transporters and enzymes responsible for the metabolism and elimination of endogenous compounds and xenobiotics. It is remarkably promiscuous and shows a broad ligand specificity ${ }^{60,61}$. It plays a key role in the metabolism and eventual elimination of steroids, bile salts and environmental contaminants across species ${ }^{60}$. PXR is expressed in prostate cancer but its expression levels in localized disease decreases in Gleason scores above $6^{61,62}$. High PXR expression in radical prostatectomy specimens is associated with better prognosis and increased survival $^{62}$. PXR induces the expression of hydroxysteroid sulfotransferase (SULT)2A1 and several members of cytochrome p450 
CYP3A enzymes, which contribute to the metabolic deactivation of androgens ${ }^{63}$. In human prostate cancer, PXR partially inhibits androgendependent cell proliferation, but has no effect in androgen-independent proliferation $^{63}$. Interestingly, despite the antiandrogenic effects, it does not cause reproductive defects in a normal individual, perhaps due to hypothalamus-pituitary testis axis compensation ${ }^{63}$. Recent evidence suggests that PXR also acts as a negative regulator of apoptosis, via downregulation of $\mathrm{p} 53^{64}$. Hence, it can promote a malignant phenotype. In addition, it plays a major role in the detoxification of chemotherapeutics ${ }^{61}$. Pre-activation of PXR leads to increased resistance to chemotherapy in prostate cancer cells ${ }^{61,62}$. The downregulation of PXR re-sensitizes these cells to chemotherapy. Moreover, the expression of PXR increases in the castration resistant setting ${ }^{62}$. This suggests that PXR in later stages plays a role in the metabolic clearance of therapeutic compounds and the development of a treatment-resistant phenotype.

\section{TLX receptor}

TLX is an evolutionary conserved nuclear receptor that plays a critical role in embryonic and adult neurogenesis ${ }^{65,66}$. It is usually found in proliferating neural progenitors, regulating adult neural stem cell renewal $^{65,66,67}$. It has been suggested that retinoids can act as ligands ${ }^{65}$. Aberrations in the TLX gene leads to loss of neurogenesis, retinopathies, psychiatric conditions and nervous system tumors. TLX expression in neural stem cells is crucial for maintaining their undifferentiated state $^{65,66,67}$. The expression of TLX decreases as the neural progenitor cells differentiate ${ }^{67}$. Target genes include PTEN, GFAP, p21 and Pax $2^{65,67}$. TLX can suppress oncogene induced senescence, thus contributing to the proliferating phenotype and also promoting tumorigenesis $^{68}$. TLX is the most frequently altered orphan nuclear receptor in prostate cancer ${ }^{61}$. Its expression levels are increased in high Gleason score disease and several prostate cancer cell lines ${ }^{69}$. It was shown that TLX overexpression has pro-tumorigenic effects in prostate cancer, while its knockdown triggers cellular senescence and growth arrest in vitro and in vivo ${ }^{69}$. Upregulation of TLX prevents prostate epithelial neoplasia cells from undergoing senescence during PTEN knockdown or oncogene $\mathrm{H}$-Ras activation, via CDKN1A repression and SIRT1 transactivation ${ }^{69}$. It can also repress $\mathrm{p} 21$, which is a prominent senescence-related gene ${ }^{68}$. In addition, TLX can confer resistance to androgen deprivation and anti-androgens ${ }^{70}$. Interestingly, it can directly suppress AR gene transcription and signaling in prostate cancer cells that are already castration resistant, regardless of the androgen stimulation status $^{70}$. TLX can bind directly to the AR promoter and repress the transcription of AR, via recruitment of histone modifiers, such as LSD1, HDAC1 and HDAC3. At the same time, it increases the expression of neuroendocrine markers ${ }^{70}$.

\section{Estrogen-related receptors}

It has been suggested that the first ancestral steroid receptor was closer to the estrogen receptor (ER $)^{71}$. Although steroid receptors are not found outside vertebrates, an ortholog of the estrogen-related receptor (ERR) is present in the genome of Drosophila melanogaster ${ }^{71}$. ERRs have three subtypes, $\operatorname{ERR} \alpha, \operatorname{ERR} \beta$ and $\operatorname{ERR} \gamma^{72,73}$. They are constitutively active 
without the presence of estrogens ${ }^{73}$. However, they bind to the same response elements as the ER and there is a crosstalk and overlap between their downstream signaling pathways ${ }^{61}$. The ERR family interacts with the transcriptional co-regulators PGC1-alpha and PGC1-beta and plays a central role in mitochondrial biogenesis and the regulation of cellular energy metabolism ${ }^{72,73}$. ERRs respond to changes in nutrients and energy demands, to regulate multiple metabolic activities and orchestrate growth and differentiation ${ }^{72,73}$. Although the expression of ERR $\beta$ in normal prostate tissue is high, it is lost in cancer ${ }^{61,74}$. On the other hand, ERR $\alpha$ and ERR $\gamma$ are consistently expressed in prostate cancer ${ }^{61,75}$. High ERR $\alpha$ expression is a poor prognostic factor ${ }^{75}$. ERR $\alpha$ protects against hypoxia and enhances tumor cell proliferation and invasiveness in prostate cancer ${ }^{76,77,78}$. It also binds to androgen response elements (AREs) and drives AR gene transcription and signaling, independently from $\mathrm{AR}^{79}$. ERR $\alpha$ also contributes to castration resistance via direct transactivation of the androgen synthesis enzymes AKR1C3 and CYP11 $1^{80}$. In addition, it can modulate prostate cancer cell metabolism, by regulating metabolic pathways downstream from the master regulator $\mathrm{AMP}^{81}$. The expression of ERR $\gamma$ is slightly lower in prostate cancer compared to normal prostate tissue. It has been shown that ERR $\gamma$ can inhibit tumor growth and reduce cellular proliferation in prostate cancer cell lines, by inducing p21 and p2 $7^{61,82}$.

\section{Dax1 and Shp}

Dax1 is a nuclear receptor that lacks a DNA-binding domain ${ }^{61,83}$. It binds to other chromatin-bound nuclear receptors, such as AR and ER, and inhibits their action ${ }^{84,85}$. The interaction between Dax1 and the nuclear receptors blocks the binding of coactivators, and encourages the recruitment of corepressors ${ }^{61,86}$. It also inhibits the dimerization of $\mathrm{AR}^{61,87}$. During embryonic development, Dax1 plays an important role in the normal development of hormone producing tissues ${ }^{88}$. In addition, it regulates the production of steroid hormones in these tissues ${ }^{89}$. It acts antagonistically to the SRY gene and Dax1 locus duplication is associated with male-to-female reversal ${ }^{90}$. Mutations in the Dax1 gene cause hypogonadotropic hypogonadism and $\mathrm{X}$-linked congenital adrenal hyperplasia ${ }^{91,92}$. Dax1 was shown to repress AR activity in LNCaP cells ${ }^{86,93}$. Its expression in prostate cancer is inversely correlated with Gleason score ${ }^{94}$. Dax1 inhibition with oncomiR miR-181 promotes prostate cancer cell proliferation ${ }^{93}$. The short heterodimeric partner (Shp) is a similar orphan nuclear receptor that lacks a DNA-binding domain $^{61,95}$. It also affects the transcriptional activity of chromatin-bound nuclear receptors by interfering with the coregulator interactions ${ }^{61,95}$. Moreover, Shp intercepts with the DNA binding of nuclear receptors ${ }^{96}$. Overall, it interacts with several other nuclear receptors, including the androgen receptor ${ }^{95,97}$. Shp acts as a mediating factor in the metabolic circadian clock $^{98}$. It has been shown that some atypical retinoids can act as ligands to promote its activity ${ }^{99}$. MiR-141 results in translational suppression of Shp, while phenethyl isothiocyanate (which is found in many edible cruciferous vegetables) increases its expression ${ }^{100}$. Shp is downregulated in multiple prostate cancer cell lines ${ }^{100}$. Its overexpression attenuates AR signaling in LNCaP cells ${ }^{100,101}$. Shp was also shown to induce apoptosis in DU-145 prostate cancer cells ${ }^{102}$. 


\section{Conclusions}

There is a "zoo" of receptors that play key roles in prostate cancer. The significance of the orphan receptors has been relatively underappreciated, but recent findings highlight their importance in the development and progression of prostate cancer. Several orphan receptors can be activated by endogenous compounds. Most have a wide specificity for ligands. Some have pro- and others have anti-tumorigenic activity. This underscores the complexity of molecular signaling inside the cancer cells. Experimental evidence has shown that targeting the activity of these orphan receptors can have a significant impact in the progression of the disease. This raises the possibility that future scientific and technological advances might enable every patient's tumor to be analyzed not only for genetic aberrations, but also for receptor expression status. Aberrations in orphan receptors might provide additional therapeutic targets that can be targeted with limited toxicity.

Acknowledgements: No acknowledgements

Conflicts of interest: All authors report no conflict of interest.

Funding:No funding

\section{References}

1. Giguère V. Orphan nuclear receptors: from gene to function. Endocr Rev. 1999 Oct;20(5):689725. doi: 10.1210/edrv.20.5.0378.

2. Nanduri R, Bhutani I, Somavarapu AK, Mahajan S, Parkesh R, Gupta P. ONRLDB--manually curated database of experimentally validated ligands for orphan nuclear receptors: insights into new drug discovery. Database (Oxford). 2015 Dec 4;2015:bav112. doi: 10.1093/database/bav112.

3. Levoye A, Dam J, Ayoub MA, Guillaume JL, Jockers R. Do orphan G-protein-coupled receptors have ligand-independent functions? New insights from receptor heterodimers. EMBO Rep. 2006 Nov;7(11):1094-8. doi: 10.1038/sj.embor.7400838.

4. Benoit G, Cooney A, Giguere V, Ingraham H, Lazar M, Muscat G, Perlmann T, Renaud JP, Schwabe J, Sladek F, Tsai MJ, Laudet V. International Union of Pharmacology. LXVI. Orphan nuclear receptors. Pharmacol Rev. 2006 Dec;58(4):798-836. doi: 10.1124/pr.58.4.10.

5. Cherezov V, Rosenbaum DM, Hanson MA, Rasmussen SG, Thian FS, Kobilka TS, Choi HJ, Kuhn P, Weis WI, Kobilka BK, Stevens RC. High-resolution crystal structure of an engineered human beta2-adrenergic G protein-coupled receptor. Science. 2007 Nov 23;318(5854):1258-65. doi: $10.1126 /$ science.1150577.

6. Trzaskowski B, Latek D, Yuan S, Ghoshdastider U, Debinski A, Filipek S. Action of molecular switches in GPCRs--theoretical and experimental studies. Curr Med Chem. 2012;19(8):1090109. doi: 10.2174/092986712799320556.

7. Tang XL, Wang Y, Li DL, Luo J, Liu MY. Orphan G protein-coupled receptors (GPCRs): biological functions and potential drug targets. Acta Pharmacol Sin. 2012 Mar;33(3):363-71. doi: 10.1038/aps.2011.210.

8. King N, Hittinger CT, Carroll SB. Evolution of key cell signaling and adhesion protein families predates animal origins. Science. 2003 Jul 18;301(5631):361-3. doi: 10.1126/science.1083853.

9. Gilman AG. G proteins: transducers of receptor-generated signals. Annu Rev Biochem. 1987;56:615-49. doi: 10.1146/annurev.bi.56.070187.003151.

10. Hauser AS, Attwood MM, Rask-Andersen M, Schiöth HB, Gloriam DE. Trends in GPCR drug discovery: new agents, targets and indications. Nat Rev Drug Discov. 2017 Dec;16(12):829-842. doi: 10.1038/nrd.2017.178. 
11. Meyerhof W, Batram C, Kuhn C, Brockhoff A, Chudoba E, Bufe B, Appendino G, Behrens M. The molecular receptive ranges of human TAS2R bitter taste receptors. Chem Senses. 2010 Feb;35(2):157-70. doi: 10.1093/chemse/bjp092.

12. de Vera IMS. Advances in Orphan Nuclear Receptor Pharmacology: A New Era in Drug Discovery. ACS Pharmacol Transl Sci. 2018 Sep 14;1(2):134-137. doi: 10.1021/acsptsci.8b00029.

13. Blumberg B, Evans RM. Orphan nuclear receptors--new ligands and new possibilities. Genes Dev. 1998 Oct 15;12(20):3149-55. doi: 10.1101/gad.12.20.3149.

14. Mi LZ, Devarakonda S, Harp JM, Han Q, Pellicciari R, Willson TM, Khorasanizadeh S, Rastinejad F. Structural basis for bile acid binding and activation of the nuclear receptor FXR. Mol Cell. 2003 Apr;11(4):1093-100. doi: 10.1016/s1097-2765(03)00112-6.

15. Edwards PA, Kennedy MA, Mak PA. LXRs; oxysterol-activated nuclear receptors that regulate genes controlling lipid homeostasis. Vascul Pharmacol. 2002 Apr;38(4):249-56. doi: 10.1016/s1537-1891(02)00175-1.

16. Siegel R, Ma J, Zou Z, Jemal A. Cancer statistics, 2014. CA Cancer J Clin. 2014 Jan-Feb;64(1):929. doi: 10.3322/caac.21208. Epub 2014 Jan 7. Erratum in: CA Cancer J Clin. 2014 SepOct;64(5):364.

17. Culig Z, Santer FR. Androgen receptor signaling in prostate cancer. Cancer Metastasis Rev. 2014 Sep;33(2-3):413-27. doi: 10.1007/s10555-013-9474-0.

18. Shiota M, Fujimoto N, Kashiwagi E, Eto M. The Role of Nuclear Receptors in Prostate Cancer. Cells. 2019 Jun 17;8(6):602. doi: 10.3390/cells8060602.

19. Daaka Y. G proteins in cancer: the prostate cancer paradigm. Sci STKE. 2004 Jan 13;2004(216):re2. doi: 10.1126/stke.2162004re2.

20. Drake JM, Graham NA, Stoyanova T, Sedghi A, Goldstein AS, Cai H, Smith DA, Zhang H, Komisopoulou E, Huang J, Graeber TG, Witte ON. Oncogene-specific activation of tyrosine kinase networks during prostate cancer progression. Proc Natl Acad Sci U S A. 2012 Jan 31;109(5):1643-8. doi: 10.1073/pnas.1120985109.

21. Poncelet G, Shimeld SM. The evolutionary origins of the vertebrate olfactory system. Open Biol. 2020 Dec;10(12):200330. doi: 10.1098/rsob.200330.

22. Niimura Y. On the origin and evolution of vertebrate olfactory receptor genes: comparative genome analysis among 23 chordate species. Genome Biol Evol. 2009 Apr 30;1:34-44. doi: 10.1093/gbe/evp003.

23. Go Y, Niimura Y. Similar numbers but different repertoires of olfactory receptor genes in humans and chimpanzees. Mol Biol Evol. 2008 Sep;25(9):1897-907. doi: 10.1093/molbev/msn135.

24. Nei M, Niimura Y, Nozawa M. The evolution of animal chemosensory receptor gene repertoires: roles of chance and necessity. Nat Rev Genet. 2008 Dec;9(12):951-63. doi: 10.1038/nrg2480.

25. Mainland JD, Li YR, Zhou T, Liu WL, Matsunami H. Human olfactory receptor responses to odorants. Sci Data. 2015 Feb 3;2:150002. doi: 10.1038/sdata.2015.2.

26. Jones DT, Reed RR. Golf: an olfactory neuron specific-G protein involved in odorant signal transduction. Science. 1989 May 19;244(4906):790-5. doi: 10.1126/science.2499043.

27. Firestein S. How the olfactory system makes sense of scents. Nature. 2001 Sep 13;413(6852):2118. doi: 10.1038/35093026.

28. Ranzani M, Iyer V, Ibarra-Soria X, Del Castillo Velasco-Herrera M, Garnett M, Logan D, Adams DJ. Revisiting olfactory receptors as putative drivers of cancer. Wellcome Open Res. 2017 Feb 10;2:9. doi: 10.12688/wellcomeopenres.10646.1.

29. Mombaerts P. Axonal wiring in the mouse olfactory system. Annu Rev Cell Dev Biol. 2006;22:713-37. doi: 10.1146/annurev.cellbio.21.012804.093915.

30. Busse D, Kudella P, Grüning NM, Gisselmann G, Ständer S, Luger T, Jacobsen F, Steinsträßer L, Paus R, Gkogkolou P, Böhm M, Hatt H, Benecke H. A synthetic sandalwood odorant induces wound-healing processes in human keratinocytes via the olfactory receptor OR2AT4. J Invest Dermatol. 2014 Nov;134(11):2823-2832. doi: 10.1038/jid.2014.273. 
31. Chéret J, Bertolini M, Ponce L, Lehmann J, Tsai T, Alam M, Hatt H, Paus R. Olfactory receptor OR2AT4 regulates human hair growth. Nat Commun. 2018 Sep 18;9(1):3624. doi: 10.1038/s41467-018-05973-0.

32. Masjedi S, Zwiebel LJ, Giorgio TD. Olfactory receptor gene abundance in invasive breast carcinoma. Sci Rep. 2019 Sep 24;9(1):13736. doi: 10.1038/s41598-019-50085-4.

33. Tong T, Wang Y, Kang SG, Huang K. Ectopic Odorant Receptor Responding to Flavor Compounds: Versatile Roles in Health and Disease. Pharmaceutics. 2021 Aug 23;13(8):1314. doi: 10.3390/pharmaceutics13081314.

34. Pronin A, Slepak V. Ectopically expressed olfactory receptors OR51E1 and OR51E2 suppress proliferation and promote cell death in a prostate cancer cell line. J Biol Chem. 2021 JanJun;296:100475. doi: 10.1016/j.jbc.2021.100475.

35. Xie H, Liu T, Chen J, Yang Z, Xu S, Fan Y, Zeng J, Chen Y, Ma Z, Gao Y, He D, Li L. Activation of PSGR with $\beta$-ionone suppresses prostate cancer progression by blocking androgen receptor nuclear translocation. Cancer Lett. 2019 Jul 1;453:193-205. doi: 10.1016/j.canlet.2019.03.044.

36. Sanz G, Leray I, Dewaele A, Sobilo J, Lerondel S, Bouet S, Grébert D, Monnerie R, Pajot-Augy E, Mir LM. Promotion of cancer cell invasiveness and metastasis emergence caused by olfactory receptor stimulation. PLoS One. 2014 Jan 8;9(1):e85110. doi: 10.1371/journal.pone.0085110.

37. Neuhaus EM, Zhang W, Gelis L, Deng Y, Noldus J, Hatt H. Activation of an olfactory receptor inhibits proliferation of prostate cancer cells. J Biol Chem. 2009 Jun 12;284(24):16218-16225. doi: 10.1074/jbc.M109.012096.

38. Xu LL, Stackhouse BG, Florence K, Zhang W, Shanmugam N, Sesterhenn IA, Zou Z, Srikantan V, Augustus M, Roschke V, Carter K, McLeod DG, Moul JW, Soppett D, Srivastava S. PSGR, a novel prostate-specific gene with homology to a $\mathrm{G}$ protein-coupled receptor, is overexpressed in prostate cancer. Cancer Res. 2000 Dec 1;60(23):6568-72.

39. Chung-Davidson YW, Rees CB, Bryan MB, Li W. Neurogenic and neuroendocrine effects of goldfish pheromones. J Neurosci. 2008 Dec 31;28(53):14492-9. doi: 10.1523/JNEUROSCI.358908.2008.

40. Mak GK, Enwere EK, Gregg C, Pakarainen T, Poutanen M, Huhtaniemi I, Weiss S. Male pheromone-stimulated neurogenesis in the adult female brain: possible role in mating behavior. Nat Neurosci. 2007 Aug;10(8):1003-11. doi: 10.1038/nn1928.

41. Abaffy T, Bain JR, Muehlbauer MJ, Spasojevic I, Lodha S, Bruguera E, O'Neal SK, Kim SY, Matsunami H. A Testosterone Metabolite 19-Hydroxyandrostenedione Induces Neuroendocrine Trans-Differentiation of Prostate Cancer Cells via an Ectopic Olfactory Receptor. Front Oncol. 2018 May 28;8:162. doi: 10.3389/fonc.2018.00162.

42. Martin LTP, Nachtigal MW, Selman T, Nguyen E, Salsman J, Dellaire G, Dupré DJ. Bitter taste receptors are expressed in human epithelial ovarian and prostate cancers cells and noscapine stimulation impacts cell survival. Mol Cell Biochem. 2019 Apr;454(1-2):203-214. doi: 10.1007/s11010-018-3464-z.

43. Singh M. Mood, food, and obesity. Front Psychol. 2014 Sep 1;5:925. doi: 10.3389/fpsyg.2014.00925.

44. Fischer A, Gilad Y, Man O, Pääbo S. Evolution of bitter taste receptors in humans and apes. Mol Biol Evol. 2005 Mar;22(3):432-6. doi: 10.1093/molbev/msi027. Epub 2004 Oct 20. Erratum in: Mol Biol Evol. 2005 Apr;22(4):1157.

45. Jeruzal-Świątecka J, Fendler W, Pietruszewska W. Clinical Role of Extraoral Bitter Taste Receptors. Int J Mol Sci. 2020 Jul 21;21(14):5156. doi: 10.3390/ijms21145156.

46. Zehentner S, Reiner AT, Grimm C, Somoza V. The Role of Bitter Taste Receptors in Cancer: A Systematic Review. Cancers (Basel). 2021 Nov 23;13(23):5891. doi: 10.3390/cancers13235891.

47. Salvestrini V, Ciciarello M, Pensato V, Simonetti G, Laginestra MA, Bruno S, Pazzaglia M, De Marchi E, Forte D, Orecchioni S, Martinelli G, Bertolini F, Méndez-Ferrer S, Adinolfi E, Di Virgilio F, Cavo M, Curti A. Denatonium as a Bitter Taste Receptor Agonist Modifies Transcriptomic Profile and Functions of Acute Myeloid Leukemia Cells. Front Oncol. 2020 Jul 24;10:1225. doi: 10.3389/fonc.2020.01225. Erratum in: Front Oncol. 2021 Apr 08;11:668460. 
48. Seo Y, Kim YS, Lee KE, Park TH, Kim Y. Anti-cancer stemness and anti-invasive activity of bitter taste receptors, TAS2R8 and TAS2R10, in human neuroblastoma cells. PLoS One. 2017 May 3;12(5):e0176851. doi: 10.1371/journal.pone.0176851.

49. Ru P, Steele R, Nerurkar PV, Phillips N, Ray RB. Bitter melon extract impairs prostate cancer cell-cycle progression and delays prostatic intraepithelial neoplasia in TRAMP model. Cancer Prev Res (Phila). 2011 Dec;4(12):2122-30. doi: 10.1158/1940-6207.CAPR-11-0376.

50. Patel N, Itakura T, Jeong S, Liao CP, Roy-Burman P, Zandi E, Groshen S, Pinski J, Coetzee GA, Gross ME, Fini ME. Expression and functional role of orphan receptor GPR158 in prostate cancer growth and progression. PLoS One. 2015 Feb 18;10(2):e0117758. doi: 10.1371/journal.pone.0117758.

51. Ning K, Sundaram R, Fan W, Rogers C, Yu DH, Chionis J, Zhou D, Claassen GF, Albers A, Grifman M, Meyhack B, Brachat A, Awad T, Peppers JA, Paoni NF, Wong-Staal F, Li QX. Orphan G-protein coupled receptor GPCR-X as a novel cancer drug target: validation and mechanistic studies. Cancer Res. 2005 May 1;65;(Suppl 9):225-225.

52. Lum AM, Wang BB, Beck-Engeser GB, Li L, Channa N, Wabl M. Orphan receptor GPR110, an oncogene overexpressed in lung and prostate cancer. BMC Cancer. 2010 Feb 11;10:40. doi: 10.1186/1471-2407-10-40.

53. Zhou C, Dai X, Chen Y, Shen Y, Lei S, Xiao T, Bartfai T, Ding J, Wang MW. G protein-coupled receptor GPR160 is associated with apoptosis and cell cycle arrest of prostate cancer cells. Oncotarget. 2016 Mar 15;7(11):12823-39. doi: 10.18632/oncotarget.7313.

54. Fan J, Lv Z, Yang G, Liao TT, Xu J, Wu F, Huang Q, Guo M, Hu G, Zhou M, Duan L, Liu S, Jin Y. Retinoic Acid Receptor-Related Orphan Receptors: Critical Roles in Tumorigenesis. Front Immunol. 2018 May 31;9:1187. doi: 10.3389/fimmu.2018.01187.

55. Cook DN, Kang HS, Jetten AM. Retinoic Acid-Related Orphan Receptors (RORs): Regulatory Functions in Immunity, Development, Circadian Rhythm, and Metabolism. Nucl Receptor Res. 2015;2:101185. doi: 10.11131/2015/101185.

56. Park SC, Park IG, Kim H, Lee JM. N-Terminal Domain Mediated Regulation of ROR $\alpha 1$ Inhibits Invasive Growth in Prostate Cancer. Int J Mol Sci. 2019 Apr 4;20(7):1684. doi: 10.3390/ijms20071684.

57. Moretti RM, Marelli MM, Motta M, Polizzi D, Monestiroli S, Pratesi G, Limonta P. Activation of the orphan nuclear receptor RORalpha induces growth arrest in androgen-independent DU 145 prostate cancer cells. Prostate. 2001 Mar 1;46(4):327-35. doi: 10.1002/10970045(20010301)46:4<327::aid-pros1040>3.0.co;2-6.

58. Moretti RM, Montagnani Marelli M, Motta M, Limonta P. Role of the orphan nuclear receptor ROR alpha in the control of the metastatic behavior of androgen-independent prostate cancer cells. Oncol Rep. 2002 Sep-Oct;9(5):1139-43.

59. Wang J, Zou JX, Xue X, Cai D, Zhang Y, Duan Z, Xiang Q, Yang JC, Louie MC, Borowsky AD, Gao AC, Evans CP, Lam KS, Xu J, Kung HJ, Evans RM, Xu Y, Chen HW. ROR- $\gamma$ drives androgen receptor expression and represents a therapeutic target in castration-resistant prostate cancer. Nat Med. 2016 May;22(5):488-96. doi: 10.1038/nm.4070. Epub 2016 Mar 28. Erratum in: Nat Med. 2016 Jun 7;22(6):692.

60. Iyer M, Reschly EJ, Krasowski MD. Functional evolution of the pregnane X receptor. Expert Opin Drug Metab Toxicol. 2006 Jun;2(3):381-97. doi: 10.1517/17425255.2.3.381.

61. Leach DA, Powell SM, Bevan CL. WOMEN IN CANCER THEMATIC REVIEW: New roles for nuclear receptors in prostate cancer. Endocr Relat Cancer. 2016 Nov;23(11):T85-T108. doi: 10.1530/ERC-16-0319.

62. Matheux A, Gassiot M, Fromont G, Leenhardt F, Boulahtouf A, Fabbrizio E, Marchive C, Garcin A, Agherbi H, Combès E, Evrard A, Houédé N, Balaguer P, Gongora C, Mbatchi LC, Pourquier P. PXR Modulates the Prostate Cancer Cell Response to Afatinib by Regulating the Expression of the Monocarboxylate Transporter SLC16A1. Cancers (Basel). 2021 Jul 20;13(14):3635. doi: 10.3390/cancers13143635.

63. Zhang B, Cheng Q, Ou Z, Lee JH, Xu M, Kochhar U, Ren S, Huang M, Pflug BR, Xie W. Pregnane $X$ receptor as a therapeutic target to inhibit androgen activity. Endocrinology. 2010 Dec;151(12):5721-9. doi: 10.1210/en.2010-0708. 
64. Robbins D, Cherian $\mathrm{M}, \mathrm{Wu} \mathrm{J}$, Chen T. Human pregnane $\mathrm{X}$ receptor compromises the function of p53 and promotes malignant transformation. Cell Death Discov. 2016 Apr 18;2:16023. doi: 10.1038/cddiscovery.2016.23.

65. Griffett K, Bedia-Diaz G, Hegazy L, de Vera IMS, Wanninayake US, Billon C, Koelblen T, Wilhelm ML, Burris TP. The Orphan Nuclear Receptor TLX Is a Receptor for Synthetic and Natural Retinoids. Cell Chem Biol. 2020 Oct 15;27(10):1272-1284.e4. doi: 10.1016/j.chembiol.2020.07.013.

66. Sobhan PK, Funa K. TLX-Its Emerging Role for Neurogenesis in Health and Disease. Mol Neurobiol. 2017 Jan;54(1):272-280. doi: 10.1007/s12035-015-9608-1.

67. Shi Y, Chichung Lie D, Taupin P, Nakashima K, Ray J, Yu RT, Gage FH, Evans RM. Expression and function of orphan nuclear receptor TLX in adult neural stem cells. Nature. 2004 Jan 1;427(6969):78-83. doi: 10.1038/nature02211.

68. O'Loghlen A, Martin N, Krusche B, Pemberton H, Alonso MM, Chandler H, Brookes S, Parrinello S, Peters G, Gil J. The nuclear receptor NR2E1/TLX controls senescence. Oncogene. 2015 Jul 30;34(31):4069-4077. doi: 10.1038/onc.2014.335.

69. Wu D, Yu S, Jia L, Zou C, Xu Z, Xiao L, Wong KB, Ng CF, Chan FL. Orphan nuclear receptor TLX functions as a potent suppressor of oncogene-induced senescence in prostate cancer via its transcriptional co-regulation of the CDKN1A (p21(WAF1) (/) (CIP1) ) and SIRT1 genes. J Pathol. 2015 May;236(1):103-15. doi: 10.1002/path.4505.

70. Jia L, Wu D, Wang Y, You W, Wang Z, Xiao L, Cai G, Xu Z, Zou C, Wang F, Teoh JY, Ng CF, $\mathrm{Yu}$ S, Chan FL. Orphan nuclear receptor TLX contributes to androgen insensitivity in castration-resistant prostate cancer via its repression of androgen receptor transcription. Oncogene. 2018 Jun;37(25):3340-3355. doi: 10.1038/s41388-018-0198-z.

71. Thornton JW. Evolution of vertebrate steroid receptors from an ancestral estrogen receptor by ligand exploitation and serial genome expansions. Proc Natl Acad Sci U S A. 2001 May 8;98(10):5671-6. doi: 10.1073/pnas.091553298.

72. Schreiber SN, Knutti D, Brogli K, Uhlmann T, Kralli A. The transcriptional coactivator PGC-1 regulates the expression and activity of the orphan nuclear receptor estrogen-related receptor alpha (ERRalpha). J Biol Chem. 2003 Mar 14;278(11):9013-8. doi: 10.1074/jbc.M212923200.

73. Huss JM, Garbacz WG, Xie W. Constitutive activities of estrogen-related receptors: Transcriptional regulation of metabolism by the ERR pathways in health and disease. Biochim Biophys Acta. 2015 Sep;1852(9):1912-27. doi: 10.1016/j.bbadis.2015.06.016.

74. Cheung CP, Yu S, Wong KB, Chan LW, Lai FM, Wang X, Suetsugi M, Chen S, Chan FL. Expression and functional study of estrogen receptor-related receptors in human prostatic cells and tissues. J Clin Endocrinol Metab. 2005 Mar;90(3):1830-44. doi: 10.1210/jc.2004-1421.

75. Fujimura T, Takahashi S, Urano T, Kumagai J, Ogushi T, Horie-Inoue K, Ouchi Y, Kitamura T, Muramatsu M, Inoue S. Increased expression of estrogen-related receptor alpha (ERRalpha) is a negative prognostic predictor in human prostate cancer. Int J Cancer. 2007 Jun 1;120(11):232530. doi: 10.1002/ijc.22363.

76. Bianco S, Lanvin O, Tribollet V, Macari C, North S, Vanacker JM. Modulating estrogen receptorrelated receptor-alpha activity inhibits cell proliferation. J Biol Chem. 2009 Aug 28;284(35):23286-92. doi: 10.1074/jbc.M109.028191.

77. Zou C, Yu S, Xu Z, Wu D, Ng CF, Yao X, Yew DT, Vanacker JM, Chan FL. ERR $\alpha$ augments HIF1 signalling by directly interacting with HIF-1 $\alpha$ in normoxic and hypoxic prostate cancer cells. J Pathol. 2014 May;233(1):61-73. doi: 10.1002/path.4329.

78. Tribollet V, Barenton B, Kroiss A, Vincent S, Zhang L, Forcet C, Cerutti C, Périan S, Allioli N, Samarut J, Vanacker JM. miR-135a Inhibits the Invasion of Cancer Cells via Suppression of ERR $\alpha$. PLoS One. 2016 May 26;11(5):e0156445. doi: 10.1371/journal.pone.0156445.

79. Teyssier C, Bianco S, Lanvin O, Vanacker JM. The orphan receptor ERRalpha interferes with steroid signaling. Nucleic Acids Res. 2008 Sep;36(16):5350-61. doi: 10.1093/nar/gkn520.

80. Xu Z, Ma T, Zhou J, Gao W, Li Y, Yu S, Wang Y, Chan FL. Nuclear receptor ERR $\alpha$ contributes to castration-resistant growth of prostate cancer via its regulation of intratumoral androgen biosynthesis. Theranostics. 2020 Mar 4;10(9):4201-4216. doi: 10.7150/thno.35589. 
81. Tennakoon JB, Shi Y, Han JJ, Tsouko E, White MA, Burns AR, Zhang A, Xia X, Ilkayeva OR, Xin L, Ittmann MM, Rick FG, Schally AV, Frigo DE. Androgens regulate prostate cancer cell growth via an AMPK-PGC-1 $\alpha$-mediated metabolic switch. Oncogene. 2014 Nov 6;33(45):525161. doi: 10.1038/onc.2013.463.

82. Yu S, Wang X, Ng CF, Chen S, Chan FL. ERRgamma suppresses cell proliferation and tumor growth of androgen-sensitive and androgen-insensitive prostate cancer cells and its implication as a therapeutic target for prostate cancer. Cancer Res. 2007 May 15;67(10):4904-14. doi: 10.1158/0008-5472.CAN-06-3855.

83. Sablin EP, Woods A, Krylova IN, Hwang P, Ingraham HA, Fletterick RJ. The structure of corepressor Dax-1 bound to its target nuclear receptor LRH-1. Proc Natl Acad Sci U S A. 2008 Nov 25;105(47):18390-5. doi: 10.1073/pnas.0808936105.

84. Zhang H, Thomsen JS, Johansson L, Gustafsson JA, Treuter E. DAX-1 functions as an LXXLLcontaining corepressor for activated estrogen receptors. J Biol Chem. 2000 Dec 22;275(51):398559. doi: 10.1074/jbc.C000567200.

85. Agoulnik IU, Krause WC, Bingman WE 3rd, Rahman HT, Amrikachi M, Ayala GE, Weigel NL. Repressors of androgen and progesterone receptor action. J Biol Chem. 2003 Aug 15;278(33):31136-48. doi: 10.1074/jbc.M305153200.

86. Holter E, Kotaja N, Mäkela S, Strauss L, Kietz S, Jänne OA, Gustafsson JA, Palvimo JJ, Treuter E. Inhibition of androgen receptor (AR) function by the reproductive orphan nuclear receptor DAX-1. Mol Endocrinol. 2002 Mar;16(3):515-28. doi: 10.1210/mend.16.3.0804.

87. Iyer AK, McCabe ER. Molecular mechanisms of DAX1 action. Mol Genet Metab. 2004 SepOct;83(1-2):60-73. doi: 10.1016/j.ymgme.2004.07.018.

88. Ludbrook LM, Harley VR. Sex determination: a 'window' of DAX1 activity. Trends Endocrinol Metab. 2004 Apr;15(3):116-21. doi: 10.1016/j.tem.2004.02.002.

89. Lalli E, Sassone-Corsi P. DAX-1, an unusual orphan receptor at the crossroads of steroidogenic function and sexual differentiation. Mol Endocrinol. 2003 Aug;17(8):1445-53. doi: 10.1210/me.2003-0159.

90. Swain A, Narvaez V, Burgoyne P, Camerino G, Lovell-Badge R. Dax1 antagonizes Sry action in mammalian sex determination. Nature. 1998 Feb 19;391(6669):761-7. doi: 10.1038/35799.

91. Jadhav U, Harris RM, Jameson JL. Hypogonadotropic hypogonadism in subjects with DAX1 mutations. Mol Cell Endocrinol. 2011 Oct 22;346(1-2):65-73. doi: 10.1016/j.mce.2011.04.017.

92. Wu SM, Gao JZ, He B, Long WJ, Luo XP, Chen L. A Novel NR0B1 Gene Mutation Causes Different Phenotypes in Two Male Patients with Congenital Adrenal Hypoplasia. Curr Med Sci. 2020 Feb;40(1):172-177. doi: 10.1007/s11596-020-2161-9.

93. Tong SJ, Liu J, Wang X, Qu LX. microRNA-181 promotes prostate cancer cell proliferation by regulating DAX-1 expression. Exp Ther Med. 2014 Oct;8(4):1296-1300. doi: 10.3892/etm.2014.1846.

94. Nakamura Y, Suzuki T, Arai Y, Sasano H. Nuclear receptor DAX1 in human prostate cancer: a novel independent biological modulator. Endocr J. 2009;56(1):39-44. doi: 10.1507/endocrj.k08e177.

95. Jouravel N, Sablin E, Arnold LA, Guy RK, Fletterick RJ. Interaction between the androgen receptor and a segment of its corepressor SHP. Acta Crystallogr D Biol Crystallogr. 2007 Nov;63(Pt 11):1198-200. doi: 10.1107/S0907444907045702.

96. Zhang Y, Soto J, Park K, Viswanath G, Kuwada S, Abel ED, Wang L. Nuclear receptor SHP, a death receptor that targets mitochondria, induces apoptosis and inhibits tumor growth. Mol Cell Biol. 2010 Mar;30(6):1341-56. doi: 10.1128/MCB.01076-09.

97. Zhang Y, Hagedorn CH, Wang L. Role of nuclear receptor SHP in metabolism and cancer. Biochim Biophys Acta. 2011 Aug;1812(8):893-908. doi: 10.1016/j.bbadis.2010.10.006.

98. Wu N, Kim KH, Zhou Y, Lee JM, Kettner NM, Mamrosh JL, Choi S, Fu L, Moore DD. Small Heterodimer Partner (NR0B2) Coordinates Nutrient Signaling and the Circadian Clock in Mice. Mol Endocrinol. 2016 Sep;30(9):988-95. doi: 10.1210/me.2015-1295.

99. Cellanetti M, Gunda V, Wang L, Macchiarulo A, Pellicciari R. Insights into the binding mode and mechanism of action of some atypical retinoids as ligands of the small heterodimer partner (SHP). J Comput Aided Mol Des. 2010 Nov;24(11):943-56. doi: 10.1007/s10822-010-9386-9. 
100. Xiao J, Gong AY, Eischeid AN, Chen D, Deng C, Young CY, Chen XM. miR-141 modulates androgen receptor transcriptional activity in human prostate cancer cells through targeting the small heterodimer partner protein. Prostate. 2012 Oct 1;72(14):1514-22. doi: 10.1002/pros.22501.

101. Gobinet J, Auzou G, Nicolas JC, Sultan C, Jalaguier S. Characterization of the interaction between androgen receptor and a new transcriptional inhibitor, SHP. Biochemistry. 2001 Dec 18;40(50):15369-77. doi: 10.1021/bi011384o.

102. Dawson MI, Xia Z, Liu G, Ye M, Fontana JA, Farhana L, Patel BB, Arumugarajah S, Bhuiyan M, Zhang XK, Han YH, Stallcup WB, Fukushi J, Mustelin T, Tautz L, Su Y, Harris DL, Waleh N, Hobbs PD, Jong L, Chao WR, Schiff LJ, Sani BP. An adamantyl-substituted retinoid-derived molecule that inhibits cancer cell growth and angiogenesis by inducing apoptosis and binds to small heterodimer partner nuclear receptor: effects of modifying its carboxylate group on apoptosis, proliferation, and protein-tyrosine phosphatase activity. J Med Chem. 2007 May 31;50(11):2622-39. doi: 10.1021/jm0613323. Epub 2007 May 10. Erratum in: J Med Chem. 2008 Oct 9;51(19):6236. Ye, Mao [added]. 